Kodifikasia : Jurnal Penelitian Islam, Vol 14, No. 02 (2020), 339-358

DOI : 10.21154/kodifikasia.v14i2.2192

ISSN : 1907-6371 (Cetak)

ISSN : 2527-9254 (Online)

\title{
DIALEKTIKA KESENIAN JARANAN THEK DI PONOROGO DENGAN ISLAM
}

\author{
Ahmad Choirul Rofiq*, Erwin Yudi Prahara*
}

\begin{abstract}
Abstrak:
Agama Islam senantiasa berinteraksi dengan kebudayaan lokal. Di antara kesenian yang berinteraksi dan berdialektika dengan ajaran agama Islam adalah kesenian Jaranan Thek di Ponorogo. Keunikan dari kesenian Jaranan Thek ini adalah para pemain dan pawang yang memainkan Jaranan Thek menggunakan unsur magis dan kadang tidak sadar (trance), padahal mereka secara formal menganut agama Islam. Oleh karena itu, penelitian ini sangat penting dalam mengkaji fenomena Jaranan Thek yang hingga kini tetap eksis dan bagaimana para pelaku kesenian ini mendealektikakannya dengan ajaran agama Islam. Penelitian kualitatif (dengan observasi, wawancara mendalam, dan dokumentasi) ini menganalisis sejarah kesenian Jaranan Thek, strategi pelestarian, dan dialektikanya dengan Islam. Jaranan Thek di Ponorogo terkait dengan Kerajaan Kediri dan Kerajaan Bantarangin (Ponorogo). Demi pelestarian Jaranan Thek, maka komunitas kesenian ini berinovasi, yakni menyisipkan kisah Kelono Sewandono (dari Kerajaan Bantarangin) dengan Dewi Songgolangit (dari Kerajaan Kediri); menambahkan variasi lagu (shalawatan, tembang Jawa, Campursari, maupun lagu populer di masyarakat); menggunakan alat musik modern (misalnya, drum dan organ elektrik) sambil mempertahankan gamelan; menggabungkan Jaranan Thek dengan kesenian lain (misalnya, tari tayuban dan jathilan); dan menyelaraskannya dengan ajaran Islam (misalnya, doa, ayat, maupun lafadh bernuansa Islam). Dialektika Jaranan Thek dengan Islam terwujud secara mencolok dalam bentuk sinkretisme setelah unsurunsur keislaman dimasukkan dalam pementasan Jaranan Thek.
\end{abstract}

Kata Kunci: Kesenian jaranan thek Ponorogo; Islam; Sinkretisme ac.id

* Institut Agama Islam Negeri Ponorogo, email: ahmadchoirulrofiq@iainponorogo.

** Institut Agama Islam Negeri Ponorogo, email: erwinyudiprahara@iainponorogo. ac.id 


\begin{abstract}
:
Islam always interacts with the local culture. Among of the arts that interact and dialectic with Islamic teachings is the art of Jaranan Thek in Ponorogo. The uniqueness of this Jaranan Thek art is that the players and handlers who play Jaranan Thek use magical elements and are sometimes unconscious (trance), even though they formally adhere to Islam. Therefore, this research is very important in examining the phenomenon of Jaranan Thek, which still exists today and how the actors of this art treat it with Islamic teachings. This qualitative research (with observations, in-depth interviews, and documentation) analyzes the history of Jaranan Thek, its conservation strategy, and its dialectic with Islam. The Jaranan Thek's art in Ponorogo related to the Kingdom of Kediri and the Kingdom of Bantarangin (Ponorogo) because Jaranan Thek's art was from Jaranan art in Kediri. There are many innovations to preserve Jaranan Thek, such as inserting the story of Kelono Sewandono (from Bantarangin Kingdom) with Dewi Songgolangit (from Kediri Kingdom); performing various songs (with shalawatan, Javanese song, Campursari, and popular songs); using modern musical instruments (drums and electric organs) besides gamelan (traditional music instruments); combining Jaranan Thek with other arts (tayuban and jathilan), and synchronizing Jaranan Thek with Islam (Islamic prayers, verses, and sayings). The dialectic of Jaranan Thek with Islam appears prominently in its syncretism with Islamic elements in its performance.
\end{abstract}

Keywords: Ponorogo jaranan thek art; Islam; Syncretism

\title{
PENDAHULUAN
}

Indonesia adalah negara yang terdiri dari banyak pulau dan memiliki suku bangsa yang berbeda-beda. Hal ini membuat Indonesia memiliki kebudayaan yang beraneka ragam. Keanekaragaman budaya tersebut merupakan salah satunya adalah keanekaragaman seni tradisi. ${ }^{1}$ Kesenian adalah salah satu unsur kebudayaan yang sangat diperlukan manusia dalam memenuhi kebutuhan hidupnya. ${ }^{2}$ Tari adalah satu dari benang-benang kesinambungan yang paling kokoh pada kebudayaan Indonesia. ${ }^{3}$ Kesenian Jaranan Thek adalah salah satu kesenian khas dari Kabupaten Ponorogo

\footnotetext{
${ }^{1}$ Sidi Gazalba, Pandangan Islam tentang Kesenian (Jakarta: Bulan Bintang, 1977), 85.

2 C Israr, Sejarah Kesenian Islam (Jakarta: PT Pembangunan, 1950), 2.

3 Claire Holt, Melacak Jejak Perkembangan Seni di Indonesia (Bandung: Arti Line, 2000), 124.
}

Kodifikasia: Jurnal Penelitian Islam, Volume, 14 No. 2 Tahun 2020 
di samping seni reog. Tari Jaranan Thek merupakan tarian kelompok yang dipentaskan oleh beberapa penari.

Agama dan kebudayaan merupakan dua hal yang tidak terpisahkan, meskipun keduanya dapat dibedakan. Dalam proses penciptaan kebudayaan tersebut tidak dapat dilepaskan dari kepercayaan atau keyakinan masyarakat terhadap agama. Ajaran agama yang dipahami masyarakat membentuk pola pikir yang kemudian dituangkan dalam bentuk tradisi yang disepakati bersama. ${ }^{4}$ Tidak hanya itu, corak keagamaan masyarakat Islam di Indonesia kemudian bersifat sinkretis. Kebudayaan spiritual bangsa Indonesia pada masa pra-sejarah bercorak dinamisme dan animisme. ${ }^{5}$

Di antara kesenian yang berinteraksi dan berdialektika dengan ajaran agama Islam adalah kesenian Jaranan Thek di Ponorogo. Keunikan dari kesenian Jaranan Thek ini adalah para pemain dan pawang yang memainkan Jaranan Thek menggunakan unsur magis dan kadang tidak sadar (trance), padahal mereka secara formal menganut agama Islam. Oleh karena itu, penelitian ini sangat penting dalam mengkaji fenomena Jaranan Thek yang hingga kini tetap eksis dan bagaimana para pelaku kesenian ini mendealektikakannya dengan ajaran agama Islam. Penelitian kualitatif dengan pengumpulan data melalui dokumentasi, observasi, dan wawancara mendalama berikut ini bertujuan untuk menjelaskan sejarah kesenian Jaranan Thek di Ponorogo, strategi pelaku kesenian Jaranan Thek dalam mempertahankan eksistensi kesenian Jaranan Thek, dan dialektika yang terjadi antara kesenian Jaranan Thek di Ponorogo dengan ajaran agama Islam yang dianut para pelaku kesenian Jaranan Thek.

Di antara kajian tentang kesenian Jaranan Thek yaitu sebuah tulisan berjudul Bentuk Penyajian Kesenian Tari Jaranan Thik di Desa Coper, Kecamatan Jetis, Kabupaten Ponorogo Jawa Timur yang ditulis oleh Whinda Kartika Nugraheni tahun 2015, Dialektika Pelaku Seni dalam Mempertahankan Eksistensi: Studi Kasus Kelompok Ketoprak Ngampung Balekambang ditulis Elvan Nur Widyantoro tahun 2013, serta Living Qur an: Resepsi al-Qur `an pada Pegiat Komunitas Seni Reyog Ponorogo oleh Muh. Tasrif, M. Irfan Riyadi, dan Anwar Mujahidin tahun 2016. Walaupun terdapat tulisan yang mengkaji tentang kesenian Jaranan Thek, namun hingga saat ini tidak dijumpai tulisan yang membahas hubungan antara kesenian Jaranan Thek dengan agama Islam yang dianut para pelaku kesenian itu.

${ }^{4}$ Ali Sodiqin, "Dasar Teologis Integrasi Islam dan Budaya Lokal," dalam Islam dan Budaya Lokal (Yogyakarta: UIN Sunan Kalijaga, 2009), 1-2.

${ }_{5}$ Ahmad Choirul Rofiq, "Kebijakan Pemerintah terkait Hak Sipil Penghayat Kepercayaan dan Implikasinya terhadap Perkembangan Penghayat Kepercayaan di Ponorogo," Kodifikasia 8, no. 1 (2014), 9-10. 
Penelitian kualitatif mengenai dialektika Jaranan Thek dengan Islam mengumpulkan data yang relevan melalui observasi dan dokumentasi terhadap pementasan Jaranan Thek, serta wawancara mendalam kepada para pegiat kesenian ini. Untuk mengungkapkan strategi mempertahankan eksistensi Jaranan Thek dan dialektikanya dengan ajaran Islam, maka dipergunakan teori fungsionalisme. Selanjutnya seluruh data dianalisis sehingga menjawab permasalahan utama penelitian.

\section{PEMBAHASAN}

\section{Seni Jaranan Thek Ponorogo dalam Tinjauan Historis}

Kehidupan manusia tidak dapat dilepaskan dari kebudayaan karena manusia mempunyai kemampuan untuk memproduksi kebudayaan. Menurut Sumarno (pemilik Paguyuban Jaranan Thek Turonggo Sakti Nogo Runcing, Dusun Mbayuripan, Desa Waringin Anom, Kecamatan Sambit, Ponorogo), kesenian jaranan merupakan kesenian nusantara dan sudah ada sejak zaman Kerajaan Kediri. Kesenian jaranan memiliki perbedaan antar daerah. Ada beberapa jenis kesenian jaranan dan ada beberapa istilah untuk menyebut jaranan tersebut. Di daerah Madiun dikenal dengan sebutan Jaranan, di daerah Kediri dikenal dengan Jaranan Pegon, di daerah Tulungagung dikenal dengan Jaranan Sentherewe, sedangkan di Ponorogo lebih dikenal Jaranan Thek. Masing-masing kesenian jaranan tiap daerah tersebut memiliki kekhasan tersendiri. ${ }^{6}$

Kesenian Jaranan Thek Ponorogo bersumber dari kesenian jaranan di Kediri yang dikembangkan oleh para seniman Ponorogo. ${ }^{7}$ Hampir di seluruh daerah di Ponorogo terdapat tokoh kesenian Jaranan Thek masingmasing. Menurut Longgar (ketua Paguyuban Jaranan Turonggo Seto, Dusun Manyur, Desa Crabak, Kecamatan Slahung, Ponorogo), paguyuban Jaranan Thek yang bernama Turonggo Wengker merupakan sebagai salah satu pelopor kemunculan kesenian Jaranan Thek di Ponorogo. Tetapi paguyuban pertama Jaranan Thek di Ponorogo belum diketahui, meskipun Sumarno meyakini bahwa kesenian Jaranan Thek sudah ada sejak zaman kerajaan Wengker. ${ }^{8}$ Kesenian Jaranan Thek Turonggo Wengker di Kecamatan Jetis

${ }^{6}$ Tim Peneliti, "Wawancara dengan Sumarno, Ketua Paguyuban Jaranan Thek Turonggo Sakti Nogo Runcing, Dusun Mbayuripan, Desa Waringin Anom, Kecamatan Sambit, Ponorogo" (Ponorogo, 2019).

7 Whinda Kartika Nugraheni, "Bentuk Penyajian Kesenian Tari Jaranan Thik di Desa Coper, Kecamatan Jetis, Kabupaten Ponorogo, Jawa Timur" (Universitas Negeri Yogyakarta, 2015), 23.

${ }^{8}$ Tim Peneliti, "Wawancara dengan Longgar, Ketua Paguyuban Seni Jaranan Turonggo Seto, Dusun Manyur, Desa Crabak, Kecamatan Slahung, Ponorogo" (Ponorogo, 2019); Peneliti, "Wawancara dengan Sumarno, Ketua Paguyuban Jaranan Thek Turonggo Sakti Nogo Runcing, Dusun Mbayuripan, Desa Waringin Anom, Kecamatan Sambit, Ponorogo";

Kodifikasia: Jurnal Penelitian Islam, Volume, 14 No. 2 Tahun 2020 
(Kabupaten Ponorogo) awalnya dikembangkan oleh tiga orang, yaitu Muhtarom, Supriyono, dan Sabarianto pada tahun 2009 dengan pemikiran untuk merangkul dan mengembangkan kreatifitas generasi pemuda dibuatlah sebuah komunitas yang bernama Turonggo Wengker. ${ }^{9}$

Menurut Sutrisno (Ketua Paguyuban kesenian Jaranan Thek Turonggo Mayang Djambe, Dusun Sekandang, Desa Pulung, Kec. Pulung, Ponorogo), nama asli kesenian Jaranan Thek adalah jaranan, namun karena perkembangan zaman, maka masyarakat lebih mudah mengatakan Jaranan Thek. Jaranan Thek diambil dari alat permainan berupa singo barong, barongan, atau caplokan yang juga disebut Thek karena menghasilkan suara "thek". ${ }^{10}$ Adapun menurut Agung (Ketua Paguyuban Jaranan Kridho Nogo Loreng, Dusun Pamongan, Desa Caluk, Kec. Slahung, Ponorogo), kesenian jaranan di Ponorogo sering dikenal dengan Jaranan Thek karena terdapat sebuah tokoh yang menggunakan kepala naga yang disebut barongan (atau juga disebut caplokan) yang mulutnya dapat membuka dan menutup seperti akan mencaplok mangsanya. Barongan (caplokan) itu oleh masyarakat Ponorogo lebih dikenal dengan sebutan thek. Hal ini dikarenakan suara yang dihasilkan dari topeng naga tersebut adalah "thek, thek" ketika dimainkan oleh seorang pemain. ${ }^{11}$

Dahulu kala ada seorang perempuan cantik yang bernama Dewi Songgolangit, yaitu putri dari Kerajaan Panjalu di Kediri. Banyak sekali yang ingin melamar Dewi Songgolangit, termasuk Prabu Klana Sewandana dari Kerajaan Bantarangin (Ponorogo) dan Prabu Singo Barong dari Kerajaan Lodaya (Kediri). Sebenarnya Dewi Songgolangit hanya ingin menjadi pertapa saja dan tidak mau menikah, tetapi sang ayah (Raja Airlangga) memaksanya untuk menikah. Karena banyak yang ingin melamar dirinya, maka Dewi Songgolangit membuat sayembara, yakni barangsiapa yang dapat memunculkan kesenian pertunjukan yang belum pernah ada di dunia dan mampu membuat jalan di dalam tanah, maka lamarannya akan diterima oleh Dewi Songgolangit. Sayembara tersebut hanya dapat dipenuhi oleh prabu Klana Sewandana. Perwujudan sayembara tersebut adalah sebagai berikut. Pertama, Dhadhak Merak atau Reyog Ponorogo yang diambil dari dari cerita ketika Klana Sewandana mengalahkan Prabu Singo Barong yang

\footnotetext{
"Wawancara dengan Sutrisno, Ketua Paguyuban kesenian Jaranan Thek Turonggo Mayang Djambe, Dusun Sekandang, Desa Pulung, Kec. Pulung, Ponorogo" (Ponorogo, 2019).

${ }^{9}$ Nugraheni, "Bentuk Penyajian Kesenian Tari Jaranan Thik di Desa Coper, Kecamatan Jetis, Kabupaten Ponorogo, Jawa Timur.", 23-24.

10 "Wawancara dengan Sutrisno, Ketua Paguyuban kesenian Jaranan Thek Turonggo Mayang Djambe, Dusun Sekandang, Desa Pulung, Kec. Pulung, Ponorogo.”

${ }^{11}$ Tim Peneliti, "Wawancara dengan Agung, Ketua Paguyuban Seni Jaranan Kridho Nogo Loreng, Dusun Pamongan, Desa Caluk, Kecamatan Slahung, Ponorogo” (Ponorogo, 2019).
} 
menghalanginya di perjalanan saat hendak melamar Dewi Songgolangit ke Kediri.

Kesenian ini ditampilkan dengan Gunungan merak kang cumengger wonten sak cengelipun Prabu Singa Barong (Gunungan dari bulu merak yang melekat di atas kepala singa/macan). Kedua, Tarian Bujang Ganong (dengan nama asli Pujangga Anom) yang menggambarkan ketika ia sedang membuat jalan di dalam tanah dari Bantarangin menuju Kediri. Sebagian masyarakat mempercayai wujud dari jalan ini adalah adanya Telaga Ngebel yang dipercaya tembus sampai wilayah Kediri. ${ }^{12}$ Untuk mengenang sayembara yang diadakan oleh Dewi Songgolangit dan pernikahanya dengan Kelana Sewandono inilah masyarakat Kediri membuat kesenian Jaranan. Kemudian Jaranan ini berkembang di wilayah Kabupaten Ponorogo. Kesenian Jaranan Thek Ponorogo ini berkembang pada tanggal 8 Oktober 2009 dengan dibentuknya Paguyuban Jaranan Thek Turonggo Wengker di Desa Coper, Kecamatan Jetis, Kabupaten Ponorogo. ${ }^{13}$

Adapun fungsi pementasan kesenian Jaranan Thek di Ponorogo ialah sebagai berikut. Kebudayaan merupakan suatu kekayaan yang sangat bernilai karena selain merupakan ciri khas dari suatu daerah juga menjadi suatu kepribadian daerah atau bangsa. ${ }^{14}$ Oleh karena itu, masyarakat Ponorogo berupaya mempertahankan dan melestarikan kebudayaan mereka yang terwujud dalam kesenian Jaranan Thek. Bahkan untuk memaksimalkan pelestarian kesenian ini didirikanlah organisasi bernama Ikatan Seni Jaranan Thek Ponorogo (disingkat ISJTP) yang merupakan wadah pemersatu antar paguyuban Jaranan Thek di Ponorogo. ${ }^{15}$

Selain didirikan organisasi Ikatan Seni Jaranan Thek Ponorogo pada 2017, dibuatkan pula akun media sosial untuk menampilkan kegiatankegiatan yang dilakukan oleh para seniman kesenian Jaranan Thek di Ponorogo, misalnya akun facebook. Bahkan terdapat sebagian masyarakat yang dengan sukarela mengunggah pementasan dan segala hal ikhwal terkait dengan kesenian Jaranan Thek di youtube.com sehingga masyarakat dimanapun berada dapat menyaksikan Jaranan Thek. ${ }^{16}$ Menurut Longgar,

${ }^{12}$ Peneliti, "Wawancara dengan Longgar, Ketua Paguyuban Seni Jaranan Turonggo Seto, Dusun Manyur, Desa Crabak, Kecamatan Slahung, Ponorogo"; Nugraheni, "Bentuk Penyajian Kesenian Tari Jaranan Thik di Desa Coper, Kecamatan Jetis, Kabupaten Ponorogo, Jawa Timur.", 24-25.

${ }^{13}$ Nugraheni, "Bentuk Penyajian Kesenian Tari Jaranan Thik di Desa Coper, Kecamatan Jetis, Kabupaten Ponorogo, Jawa Timur.”, 25.

${ }^{14}$ Sri Heni Pawarti Budianingsih, "Fungsi Seni Kuda Lumping bagi Masyarakat Jawa di Desa Seminai Kecamatan Kerinci Kanan Kabupaten Siak,” Jom Fisip 2, no. 1 (2015).

${ }^{15}$ Peneliti, "Wawancara dengan Sumarno, Ketua Paguyuban Jaranan Thek Turonggo Sakti Nogo Runcing, Dusun Mbayuripan, Desa Waringin Anom, Kecamatan Sambit, Ponorogo.” 26 Juni 2019.

${ }^{16}$ ISJTP, “Republik Jaranan,” 2017, https://www.facebook.com/RepublikJaranan/.

Kodifikasia: Jurnal Penelitian Islam, Volume, 14 No. 2 Tahun 2020 
hubungan antar paguyuban Jaranan Thek terjalin dengan baik. Motto dari semua paguyuban adalah "Ora ana kamulyan tanpa paseduluran" yang artinya tidak ada kemuliaan tanpa adanya persaudaraan. Pementasan Jaranan Thek biasanya di tempat terbuka bagi masyarakat umum dan diselenggarakan untuk acara-acara tertentu sesuai keinginan masyarakat. ${ }^{17}$ Dengan demikian, kesenian Jaranan Thek dapat berguna sebagai sarana hiburan bagi masyarakat Ponorogo dan sekaligus untuk pelestarian kebudayaan masyarakat Ponorogo.

\section{Upaya Pelestarian Kesenian Jaranan Thek}

Adapun pola pertunjukan Jaranan Thek di Ponorogo secara umum memiliki banyak kesamaan sehingga penjelasan mengenai pementasan Jaranan Thek dalam penelitian ini tidak jauh berbeda dengan penelitian serupa yang telah dilakukan sebelumnya oleh Whinda Kartika Nugraheni, meskipun setiap paguyuban kesenian Jaranan Thek juga memiliki kekhasan dalam pementasannya. Secara umum, pertunjukan kesenian Jaranan Thek meliputi ritual sebelum pementasan, pembukaan, tari jaran kepang, tari celeng, perang jaran dan celeng, penari barongan thek memasuki arena dan menari, semua penari melakukan tarian bersama-sama, pawang memasukkan makhluk gaib (jin) kepada para penari sehingga kesurupan dan menari mengikuti iringan lagu, pawang melakukan pemulihan kesadaran para penari, dan penutup. ${ }^{18}$

Pertunjukan Jaranan Thek diawali pembukaan dengan melakukan doa bersama dipimpin oleh tokoh paguyuban kesenian tersebut. Dalam ritual tersebut, biasanya disertai dengan pembakaran dupa atau kemenyan. Kemudian pawang atau gambuh membunyikan pecut dan berdoa untuk mengawali pertunjukan. Selain itu, pawang Jaranan Thek kadang meletakkan dupa di setiap penjuru arena pementasan, sebagaimana yang dilakukan ketika pertunjukan Jaranan Thek untuk peringatan dua tahun Ikatan Seni Jaranan Thek Ponorogo pada 2018.

Pawang memasuki arena pertunjukan dan membunyikan pecut besar untuk memanggil satu persatu pemain jaran (prajurit berkuda) agar memasuki arena pertunjukan. Setelah semua pemain jaran masuk arena pertunjukan, pemain jaran menari bersama-sama dengan diiringi musik khas Jaranan Thek. Setelah selesai menari, maka penari jaran duduk dengan kaki kiri ditekuk ke belakang dan kaki kanan berada di depan

${ }^{17}$ Peneliti, "Wawancara dengan Longgar, Ketua Paguyuban Seni Jaranan Turonggo Seto, Dusun Manyur, Desa Crabak, Kecamatan Slahung, Ponorogo.” 18 Juni 2019.

${ }^{18}$ Peneliti, "Wawancara dengan Sumarno, Ketua Paguyuban Jaranan Thek Turonggo Sakti Nogo Runcing, Dusun Mbayuripan, Desa Waringin Anom, Kecamatan Sambit, Ponorogo." 
dada. Pola tempat duduk penari adalah garis lurus dan berada di tepi arena pertunjukkan. Namun terkadang sebelum penari jaran memasuki arena, pertunjukan diawali dengan penampilan tarian lain.

Pawang memasuki arena pertunjukkan dan membunyikan pecut besar untuk memanggil satu persatu pemain Celeng (babi hutan) untuk masuk ke arena pertunjukan. Setiap penari celeng masuk arena pertunjukkan dengan menari. Penari celeng dan jaran menari seperti adegan dalam peperangan. Ada pula pawang melakukan ritual untuk memasukkan makhluk gaib (jin) ke dalam tubuh para penari jaran dan celeng sehingga mengalami kesurupan, meskipun penari barongan thek belum ditampilkan.

Satu persatu penari barongan Thek memasuki arena pertunjukkan disambut bunyi pecut seorang pawang. Semua penari thek menari bersama. Pawang melakukan ritual untuk memasukkan makhluk gaib (jin) ke dalam tubuh para penari jaranan thek. Setelah itu, para penari thek yang telah kesurupan menari bersama. Ternyata tidak hanya para penari saja yang mengalami kesurupan. Di antara penonton-penonton yang menyaksikan Jaranan Thek kadang ada pula terkena kesurupan dan ikut menari bersama para penari Jaranan Thek.

Selanjutnya, satu persatu penari Jaranan Thek (dan penonton) yang mengalami kesurupan disadarkan oleh pawang. Bahkan terkadang terdapat peristiwa unik tatkala orang yang kesurupan adalah justru sang pawang sendiri sehingga penyadaran terhadap pawang yang kesurupan itu dilakukan oleh pawang lain yang lebih mumpuni dan senior. Misalnya ketika Bapak Muhtarom kesurupan dan disadarkan oleh Bapak Boini. Pertunjukan seni Jaranan Thek ditutup oleh pawang yang membunyikan pecut besar sekaligus untuk menetralkan arena pertunjukan dari makhluk gaib. ${ }^{19}$

Sebagaimana disebutkan di atas, kebudayaan mempunyai nilai di tengah-tengah suatu masyarakat sehingga masyarakat tersebut senantiasa berupaya untuk mempertahankan dan melestarikannya. Oleh sebab itulah, kesenian Jaranan Thek dipertahankan dan dilestarikan oleh masyarakat Ponorogo melalui berbagai ikhtiar kebudayaan. Di antaranya ialah menyelenggarakan pementasan Jaranan Thek dengan rutin, mendirikan organisasi bernama Ikatan Seni Jaranan Thek Ponorogo (disingkat ISJTP) yang merupakan wadah pemersatu antar paguyuban Jaranan Thek di Ponorogo, dan melakukan improvisasi pertunjukan Jaranan Thek dengan

${ }^{19}$ Peneliti, "Wawancara dengan Longgar, Ketua Paguyuban Seni Jaranan Turonggo Seto, Dusun Manyur, Desa Crabak, Kecamatan Slahung, Ponorogo"; Tim Peneliti, "Wawancara dengan Agus, Ketua Paguyuban Seni Jaranan Thek Turonggo Wulung" (Ponorogo, 2019). 
kreasi-kreasi baru agar kesenian ini semakin diminati berbagai kalangan masyarakat. ${ }^{20}$

Dalam pandangan Parsons, setiap sistem sosial supaya dapat beroperasi dengan baik seharusnya memenuhi empat persyaratan yang disebutnya dengan istilah functional imperatives atau functional prerequisites, yaitu [1] adaptation to the environment, [2] goal attainment, [3] pattern maintenance and tension management, dan [4] integration. ${ }^{21}$ Adapun strategi komunitas Jaranan Thek dalam mempertahankan dan melestarikan eksistensi kesenian Jaranan Thek adalah sebagai berikut:

1. Penambahan Cerita dalam Pementasan

Di dalam buku Babad Ponorogo karya Purwowijoyo disebutkan mengenai sejarah Ponorogo yang penjelasannya menerangkan kisah Kerajaan Bantarangin. Sekitar 200 tahun setelah kekalahan Wengker melawan Airlangga, muncul kerajaan baru yang bernama Kerajaan Bantarangin. Letak kerajaan itu di Desa Somoroto (kira-kira $12 \mathrm{~km}$ arah barat kota Ponorogo) yang awalnya masih bagian dari Wengker. Raja Bantarangin bernama Kelono Sewandono dan patihnya bernama Kelono Wijaya, adiknya. Pada suatu malam, Kelono Sewandono bermimpi bertemu dengan putri Kediri yang bernama Dewi Songgolangit. Keesokan harinya, ia mengutus adiknya agar melamarkan Songgolangit untuknya.

Prabu Kertajaya, raja Kediri, mengetahui putrinya ketakutan melihat tamunya. Namun ia tidak berani menolak lamaran karena raja Bantarangin terkenal sakti. Oleh sebab itu, ia mengajukan persyaratan untuk proses pernikahan. Ia minta seperangkat gamelan (gong) yang belum ada di bumi ini dan digunakan untuk mengiringi jalannya temanten dari Bantarangin ke Kediri. Ia minta berbagai macam hewan di hutan yang dihalau ke Kediri untuk mengisi kebun binatang. Ia juga minta manusia berkepala harimau. Mendengar permohonan itu, Kelono Wijaya menyanggupi dan segera pulang ke Ponorogo.

Ternyata patih Kediri yang bernama Singolodro atau Barongseta juga menghendaki ingin mempersunting Dewi Songgolangit. Ia sakti dan dapat menjadi harimau putih. Ia kemudian mencegat rombongan Kelono Sewandono. Rombongan dan hewan-hewan yang telah diikat kocar-kacir. Perang tanding antara keduanya terjadi dan dimenangkan Singolodro. Saat itu, Kelono Sewandono menjerit memanggil adiknya. Kelono Wijaya kemudian datang. Dengan pecut Samandiman, ia dapat

${ }^{20}$ Peneliti, "Wawancara dengan Sumarno, Ketua Paguyuban Jaranan Thek Turonggo Sakti Nogo Runcing, Dusun Mbayuripan, Desa Waringin Anom, Kecamatan Sambit, Ponorogo."

${ }^{21}$ Cuff W.W. Sharrock, D.W. Francis, E.C, Perspectives in Sociology (London: Routledge, 1998), 40-42.

Kodifikasia: Jurnal Penelitian Islam, Volume, 14 No. 2 Tahun 2020 
mengalahkan Singolodro. Meskipun ia mengampuni Singolodro, ia tetap membiarkan kepala Singolodro berwujud kepala harimau dan menjadikannya sebagai pelengkap syarat yang dimohon oleh raja Kediri. Hewan-hewan yang lari kocar-kacir pun dapat dikumpulkan kembali dengan sangat mudah.

Setelah semuanya selesai, rombongan pengantin kembali mendatangi putri Kediri. Tetapi sesampai di sana, Dewi Songgolangit tidak ada. Ia melarikan diri ke dalam sebuah gua yang tertutup rapat. Kelono Sewandono kemudian menemui Songgolangit dan membujuknya agar mau diboyong ke Bantarangin. Karena permohonannya tidak dihiraukan dan Songgolangit selalu diam membisu, maka Kelono Sewandono marah besar atas penghinaan itu. Ia mengutuk Songgolangit menjadi batu. Kelono Sewandono pulang melewati terowongan yang dibuat oleh Kelono Wijaya dengan kesaktian pecutnya. Tempat itu disebut Gua Bedali dari kata mbedah kali (membelah sungai). Peristiwa kegagalan pernikahan dan keberangkatan rombongan pengantin lengkap dengan seluruh persyaratannya itu kemudian menjadi warisan kesenian masyarakat Ponorogo yang disebut dengan Reog atau Reyog. ${ }^{22}$

Selain jalur kesenian Reyog, penyampaian kisah antara Raja Kelono Sewandono dan Dewi Songgolangit yang sangat fenomenal di kalangan masyarakat Ponorogo tersebut juga dituturkan secara turun temurun kepada setiap generasi melalui kesenian Jaranan. ${ }^{23}$ Apabila penyampaian kisah tersebut di kesenian Reyog dan Jaranan Thek dibandingkan di antara keduanya, maka rangkaian urutan kisahnya dan pemeranan para tokohnya di kesenian Reyog lebih lengkap daripada di Jaranan Thek. Menurut Agung, setiap paguyuban satu sama lain memiliki perbedaan dalam penyajian. Antar paguyuban memiliki karakteristik tersendiri, ada yang menonjolkan bagian estetik penari dan musik, namun ada juga yang mengunggulkan bagian kesurupannya untuk menarik minat penonton. Terlepas dari itu alur cerita yang dibawakan oleh semua paguyuban tetap sama. Beberapa paguyuban juga sering menambahkan tokoh lain di luar pakem Jaranan Thek, yaitu Dewi Sekartaji, Bujang Ganong, siluman kera, siluman macan dan lain sebagainya. ${ }^{24}$

\footnotetext{
${ }^{22}$ Purwowijoyo, Babad Ponorogo (Ponorogo: Dinas Pariwisata dan Seni Budaya Pemerintah Kabupaten Ponorogo, 1985), 14-20.

${ }^{23}$ Peneliti, "Wawancara dengan Longgar, Ketua Paguyuban Seni Jaranan Turonggo Seto, Dusun Manyur, Desa Crabak, Kecamatan Slahung, Ponorogo.”, 18 Juni 2019.

${ }^{24}$ Peneliti, "Wawancara dengan Agung, Ketua Paguyuban Seni Jaranan Kridho Nogo Loreng, Dusun Pamongan, Desa Caluk, Kecamatan Slahung, Ponorogo.”, 22 Juni 2019.
} 
2. Variasi Lagu

Menurut Mbah Longgar, setiap paguyuban memiliki perbedaan dalam menampilkan atau menyajikan pertunjukan Jaranan Thek. Menurutnya setiap paguyuban memiliki ciri khas pertunjukan masing-masing. Ciri khas ini dapat dilihat dari segi format pertunjukan, gerak tari, iringan musik, dan lagu-lagu yang dinyanyikan dalam pertunjukkan. Ciri khas yang muncul dari paguyuban Jaranan Thek Turonggo Seto Crabak, yang dipimpin Mbah Longgar adalah dari segi lagu-lagu yang dinyanyikan. Sebagian lagu yang dinyanyikan dalam pertunjukkan adalah lagu yang bernuansa Islami dan sholawat, seperti lagu Kidung Wahyu Kolosebo. Demikian pula tembang-tembang Gending Jawa, Campursari, dan lagulagu yang populer di masyarakat. ${ }^{25}$

3. Penambahan Peralatan Musik dalam Kesenian Jaranan Thek

Gamelan merupakan alat musik tradisional khas Jawa yang terdiri dari laras slendro dan pelog. Diperkirakan, gamelan sudah ada di Jawa sebelum agama Islam masuk ke Indonesia. Semenjak dahulu, gamelan dibunyikan untuk meramaikan pesta-pesta yang diselenggarakan masyarakat Jawa. Kemudian pada juru dakwah Islam menggubah pemaknaan gamelan dan dipergunakan untuk sarana penyebaran agama Islam. Kedatangan agama Islam ke Jawa membawa pembaharuan dalam berbagai aspek kehidupan masyarakat, termasuk dalam kesenian dan gamelan.

Gamelan terdiri dari bermacam-macam alat yang masing-masing mempunyai nama dan fungsi yang berbeda-beda. Dalam kaitannya dengan kesenian Jaranan Thek, gamelan tidak dapat dipisahkan dalam setiap pertunjukan Jaranan Thek. Namun selain mempergunakan alat musik gamelan yang sudah lazim sejak dulu tersebut, ternyata pementasan kesenian Jaranan Thek juga memanfaatkan alat-alat musik modern, seperti drum dan organ elektrik. Dengan penambahan alat musik modern itu, maka pertunjukan Jaranan Thek semakin menarik bagi para penonton sehingga kesenian Jaranan Thek semakin diminati.

4. Kombinasi dengan Kesenian lain

Tidak hanya mempergunakan alat-alat musik modern, pementasan kesenian Jaranan Thek menggabungkan kesenian lain yang digemari masyarakat, seperti tari tayub (gambyong) dan jathilan.

5. Memasukkan Unsur Keislaman dalam Jaranan Thek

Sebagai suatu kesenian yang dikembangkan di tengah-tengah masyarakat yang mayoritas beragama Islam, maka kesenian Jaranan Thek kemudian memasukkan unsur-unsur ajaran agama Islam.

${ }^{25}$ Peneliti, "Wawancara dengan Longgar, Ketua Paguyuban Seni Jaranan Turonggo Seto, Dusun Manyur, Desa Crabak, Kecamatan Slahung, Ponorogo.” 


\section{Akulturasi Kesenian Jaranan Thek dan Islam}

Para sarjana yang menaruh minat terhadap pengkajian megenai masyarakat Jawa biasanya mengenal secara baik terhadap istilah "santri" dan "abangan". Terlebih lagi setelah muncul karya Clifford Geertz berjudul The Religion of Jawa pada 1960 yang telah mengkaji permasalahan ini dengan mendalam. ${ }^{26}$ Praktek keagamaan kelompok abangan cenderung diwarnai oleh integration of animistic, Hinduistic, and Islamic elements (penggabungan elemen animisme, Hindu, dan Islam) sehingga bersifat sinkretis. Tradisi utama keagamaan mereka biasanya diwujudkan dalam ritual slametan. Adapun praktek keagamaan kelompok santri lebih menonjol tingkat kedisiplinannya dalam pelaksanaannya sesuai dengan tuntunan agama Islam dibandingkan kelompok abangan. Sebenarnya terdapat kelompok ketiga yang disebutkan oleh Geertz, yakni priyayi yang mempunyai kedudukan tinggi secara birokratis dan praktek keagamaannya lebih bercorak Hindu (Budha). ${ }^{27}$

Banyak peneliti Indonesia modern yang tidak setuju dengan cara ketiga varian di atas dirumuskan Geertz. Dengan mengenyampingkan kontroversi sekitar unsur-unsur konseptualisasinya yang lebih substantif, sejumlah kritik diarahkan untuk menolak pembilahan-pembilahan religio-kultural seperti itu. Sementara varian abangan-santri secara luas dipandang sebagai "dikotomi yang sah yang didasarkan kepada perbedaan keagamaan," nasib yang menimpa varian priayi tidak seperti itu. Varian ini banyak dipandang sebagai status ketimbang kategori keagamaan. Karena itu, dalam kategori keagamaannya, seorang priyayi dapat masuk ke dalam varian abangan atau santri. ${ }^{28}$

Kelompok santri adalah orang Muslim saleh yang memeluk agama Islam secara sungguh-sungguh dan dengan teliti menjalankan perintahperintah agama Islam sebagaimana yang diketahuinya sambil membersihkan akidahnya dari perbuatan syirik. Sedangkan penyebutan kelompok abangan disematkan kepada orang Muslim yang tidak seberapa memperhatikan perintah-perintah agama Islam dan kurang disiplin dalam memenuhi kewajiban-kewajiban agama Islam. Namanya saja menggunakan nama Muslim, tetapi cara kehidupannya masih banyak dikuasai oleh tradisi praIslam jawa. Tradisi ini menitikberatkan pada pemaduan unsur-unsur Islam,

${ }^{26}$ Zaini Muchtarom, Islam di Jawa dalam Perspektif Santri dan Abangan (Jakarta: Salemba Diniyah, 2002), xxiii-xxiv. $5-6$.

${ }^{27}$ Clifford Geertz, Religion of Java (Chicago: The University of Chicago Press, 1990),

${ }^{28}$ Bahtiar Effendy, Islam dan Negara: Transformasi Gagasan dan Praktik Politik Islam di Indonesia (Jakarta: Democracy Project, 2011), 40-43.

Kodifikasia: Jurnal Penelitian Islam, Volume, 14 No. 2 Tahun 2020 
Buddha-Hindu, dan unsur-unsur asli sebagai sinkretisme Jawa sehingga sering dinamakan dengan agama Jawa. ${ }^{29}$

Konsepsi dasar masyarakat Jawa mengenai dunia gaib (dunia yang tidak nampak) didasarkan pada keyakinan bahwa semua perwujudan dalam kehidupan disebabkan oleh makhluk yang mempunyai kehendak sendiri. Segala sesuatu di dalam alam, di dunia hewan dan tumbuhtumbuhan mempunyai nyawanya sendiri. Nyawa atau roh yang tinggal di suatu benda mampu mengembara sekehendaknya atau berpindah-pindah. Keyakinan inilah yang masih dijumpai di kelompok abangan yang kemudian dipraktekkan secara berbarengan dengan ajaran agama Hidu maupun Islam. Roh-roh yang disembah oleh masyarakat jawa pada umumnya disebut dengan Hyang atau Yang yang berarti Tuhan sehingga Tuhan disebut dengan Hyang maha Kuwasa (Tuhan Yang Maha Kuasa) dan aktivitas shalat sehari-hari disebut dengan "sembahyang", artinya penyembahan kepada Tuhan. Dalam perkembangannya, yang inipun diperluas dengan adanya sebutan danyang desa (roh pelindung desa) yang senantiasa dihormati oleh masyarakat dengan melakukan ritual slametan agar mendapatkan perlindungan dari danyang desa tersebut sehingga keselamatan masyarakat bisa terwujud. Kepercayaan kepada roh-roh halus itupun bertambah dengan dimasukkannya kepercayaan terhadap jin, yakni makhluk gaib yang terdapat dalam ajaran agama Islam. ${ }^{30}$

Pengamatan terhadap pementasan kesenian Jaranan Thek menunjukkan adanya tradisi-tradisi pra-Islam di dalam pertunjukan kesenian tersebut. Misalnya, pemakaian sesajen, persembahan kepada makhluk halus yang diyakini sebagai arwah leluhur penjaga daerah tertentu (tempat pementasan Jaranan Thek, permintaan bantuan kepada makhluk halus agar merasuki pemain Jaranan Thek. Selain itu, penyelenggaraan kesenian Jaranan Thek juga menggunakan ayat-ayat dan doa-doa yang bernuansa keislaman sehingga pertunjukan itu secara umum memperlihatkan perpaduan antara unsur-unsur Islam dan pra-Islam. Pemaparan berikut ini berupaya menjelaskan permasalahan tersebut dengan lebih mendalam.

Praktek pemakaian sesajen merupakan tradisi yang biasanya dilakukan oleh kalangan Islam Abangan tatkala menyelenggarakan suatu ritual untuk tujuan dan maksud tertentu. Bahkan di beberapa daerah dijumpai kegiatan terkait sesajen yang disebut dengan ritual Larung Sesaji, sebagaimana dilaksanakan oleh masyarakat Ngebel, Kabupaten Ponorogo ${ }^{31}$ maupun

\footnotetext{
${ }^{29}$ Muchtarom, Islam di Jawa dalam Perspektif Santri dan Abangan, 11-14.

${ }^{30}$ Muchtarom, 55-60.

${ }^{31}$ Maulana dan Abraham Nurcahyo Mitanto, "Ritual Larung Sesaji Telaga Ngebel Ponorogo: Studi Historis dan Budaya," Agastya: Jurnal Sejarah dan Pembelajarannya 2, no.
} 2 (2012), 39-41. 
masyarakat di Sarangan, Kabupaten Magetan, Jawa Timur. ${ }^{32}$ Contoh tradisi pemberian sesajen ialah di dalam acara pernikahan, sebagaimana dilakukan di pernikahan adat Jawa di Desa Leran, Kecamatan Senori, Kabupaten Tuban. ${ }^{33}$ Tradisi pemberian sesajen juga terdapat di Desa Prenduan, Kecamatan Pragaan, Kabupaten Sumenep, Madura, yang berupa sonsonan, sontengan, dan moang na'as. ${ }^{34}$

Memang praktik pemberian sesajen biasanya tidak dapat dipisahkan dari keyakinan kaum Islam Abangan kepada makhluk gaib (makhluk halus) atau makhluk astral yang tidak kasat mata. Makhluk halus adalah makhluk yang menempati alam lain di luar alam manusia yang masih hidup. Dengan demikian, roh orang yang telah meninggal dalam kepercayaan sebagian masyarakat Jawa diyakini sebagai makhluk halus sebab roh itu menempati dimensi lain dari alam dunia. Meskipun berada di dalam dimensi lain, namun roh tersebut diyakini dapat mengawasi manusia yang masih hidup di dunia. Dari segi kehidupannya, makhluk halus juga seperti manusia umumnya yang memiliki kehidupannya di alamnya sendiri dengan struktur kehidupannya yang terdiri dari pemimpin dan bawahan yang terendah.

Di antara berbagai macam wujud makhluk halus di kalangan masyarakat Jawa itu terdapat jenis makhluk halus yang disebut dengan danyang, yakni roh halus tingkat tinggi yang tinggal di pohon, gunung, sumber mata air desa. Danyang diyakini sebagai roh para tokoh pendahulu atau leluhur suatu desa yang sudah meninggal dan berjasa dalam mendirikan desa atau membuka lahan desa itu. Ketika leluhur desa meninggal biasanya dimakamkan di tempat yang disebut sebagai punden desa. Danyang dipercaya mampu memberikan perlindungan terhadap warga desa. Danyang mempunyai pembantu yang juga berwujud roh dan disebut anak danyang yang tinggal di pojok-pojok desa. Penghormatan kepada danyang dilakukan dalam bentuk upacara slametan desa yang disebut nyadran atau sadranan di dekat makam danyang pada bulan Syuro atau Ruwah. Dalam ritual ziarah ke makam danyang itu biasanya seluruh warga desa itu dianjurkan menghadirinya dengan memberikan sesajen. ${ }^{35}$

${ }^{32}$ Dicky Reza Romadhon, "Menelisik Nilai-Nilai Kearifan Lokal dalam Upacara Tradisi Larung Sesaji di Telaga Sarangan, Desa Sarangan, Kecamatan Plaosan, Kabupaten Magetan" (Universitas Negeri Malang, 2013).

${ }^{33}$ Hariyana Khotijah, "Eksistensi Budaya Sesajen dalam Pernikahan Adat Jawa Di Desa Leran Kecamatan Senori Kabupaten Tuban” (UIN Sunan Ampel, Surabaya, 2018), 56-57.

${ }^{34}$ Aminulah, "Sinkretisme Agama dan Budaya dalam Tradisi Sesajen di Desa Prenduan," Dirosat 2, no. 1 (2017), 9-11.

${ }^{35}$ Rizem Aizid, Islam Abangan dan Kehidupannya: Seluk Beluk Kehidupan Islam Abangan (Yogyakarta: Dipta, 2015), 175-178.

Kodifikasia: Jurnal Penelitian Islam, Volume, 14 No. 2 Tahun 2020 
Keyakinan dan praktik tradisi terkait dengan keadaan arwah orang yang telah meninggal dan pemberian sesajen dalam ritual tertentu di kalangan masyarakat Islam Abangan tersebut sangat berbeda dari keyakinan yang dipraktikkan oleh masyarakat Islam ortodoks pada umumnya. Menurut ajaran syariat Islam, arwah manusia yang telah meninggal tidak dapat kembali ke alam dunia karena mereka berada di alam barzakh (atau alam transisi antara alam dunia dan alam akhirat). Allah Swt berfirman di dalam al-Qur'an: "Allah memegang jiwa (orang) ketika matinya dan (memegang) jiwa (orang) yang belum mati di waktu tidurnya; maka Dia tahanlah jiwa (orang) yang telah Dia tetapkan kematiannya dan Dia melepaskan jiwa yang lain sampai waktu yang ditentukan. Sesungguhnya pada yang demikian itu terdapat tandatanda kekuasaan Allah bagi kaum yang berpikir." (QS. Al-Zumar [39]: 42) Secara harfiah, Barzakh berarti tabir atau pemisah di antara dua hal yang tidak memungkinkan bagi keduanya untuk saling bertemu. ${ }^{36}$

Adapun makhluk halus (lelembut) atau roh leluhur yang diyakini oleh masyarakat Abangan dapat diajak berkomunikasi atau dihadirkan ketika pelaksanaan ritual maupun slametan dan diberikan sesajen untuk mereka sesungguhnya adalah jin. Makhluk gaib ini disebut jin karena menurut bahasa Arab bermakna tertutup, yakni keberadaan jin tidak terlihat oleh mata manusia umumnya, meskipun jin dapat melihat keberadaan manusia. Allah Swt juga menjelaskan bahwa jin adalah makhluk ciptaan Allah Swt yang berbeda dari malaikat maupun manusia. Malaikat diciptakan dari cahaya, sedangkan manusia diciptakan dari tanah. Keberadaan jin ditegaskan lagi dengan penamaan satu surat di dalam al-Quran dengan nama Surat al-Jinn [QS. 71]. Sifat menonjol yang dimiliki setan maupun iblis adalah pembangkangan dan kedurhakaannya kepada Allah Swt dan tingkahnya yang selalu menggoda manusia untuk melanggar perintah Allah Swt. Meskipun di antara para jin terdapat sebagian mereka yang beriman kepada Allah Swt dan kerasulan Nabi Muhammad saw.

Adapun tempat-tempat yang biasanya dihuni oleh para jin sama dengan yang diyakini oleh masyarakat Islam Abangan, yakni tempat-tempat kotor, seperti kuburan dan kamar mandi. Para jin itupun mempunyai kehidupan sebagaimana dialami oleh manusia. ${ }^{37}$ Oleh sebab itu, sangatlah wajar ketika makam atau kuburan merupakan tempat yang biasanya dijadikan lokasi untuk kegiatan penghormatan kepada leluhur oleh kaum Islam Abangan. Arwah leluhur yang disebut dengan danyang dan hakikatnya adalah jin. Penghormatan kepada danyang dilakukan dalam bentuk upacara slametan

${ }^{36}$ Aizid, 69-70.

${ }^{37}$ Umar Sulayman Al-Asyqar, 'Alam al-Jinn wa al-Syayathin (Kuwait: Maktabah alFalah, 1984), 11-12. 
desa di makam danyang (atau punden) dengan memberikan sesajen. Dengan pelaksanaan slametan itu, masyarakat Abangan mengharapkan keselamatan dan menghindari kemarahan para danyang desa. ${ }^{38}$

Demikian pula saat terjadi komunikasi antara seseorang dengan orang lain yang dirasuki oleh arwah atau danyang tertentu, maka sesungguhnya orang yang kesurupan dan kerasukan tersebut telah dirasuki oleh jin yang mengaku sebagai danyang. Apalagi jika jin itu dapat menceritakan segala hal ikhwal terkait dengan kehidupan masa lalu leluhur pendiri desa. Bahkan terdapat informasi dari agama Islam mengenai keberadaan jin yang senantiasa menyertai manusia. Jin inilah yang disebut dengan jin qarin. ${ }^{39}$

Selain pemberian sesajen dan penghormatan kepada arwah para leluhur, penyelenggaraan kesenian Jaranan Thek juga menggunakan ayatayat dan doa-doa yang bernuansa keislaman. Fenomena sosial keagamaan di tengah masyarakat semacam inilah yang disebut dengan Living Qur'an, yakni pemaknaan masyarakat terhadap al-Qur'an. ${ }^{40}$ Dalam kaitannya dengan pertunjukan Jaranan Thek, maka penggunaan ayat-ayat al-Qur'an sebagai bacaan doa-doa ketika pementasan Jaranan Thek adalah untuk mendapatkan perlindungan dari Allah Swt (Tuhan Yang Maha Esa). Selain itu, ayat-ayat al-Qur'an dapat dimanfaatkan untuk penyadaran orangorang yang kerasukan jin, ${ }^{41}$ sebagaimana dijumpai dalam pelaksanaan ruqyah terhadap pasien yang terkena gangguan jin, meskipun prosedur penyembuhannya secara detil tentunya terdapat perbedaan di antara keduanya.

Karena pertunjukan Jaranan Thek berada dalam pengawasan pawang, maka seorang pawang biasanya diharuskan memenuhi persyaratan-persyaratan tertentu. Pawang dalam seni pertunjukan jaranan merupakan pawang yang sudah terpilih, terlatih dan sudah dipercayai untuk mengatur jalannya seni pertunjukan jaranan. Pawang merupakan seseorang yang mempunyai keahlian istimewa yang berkaitan dengan ilmu gaib. Ketika penari jaranan ada yang mengalami kesurupan, maka pawang jaranan dengan segera mengobati pemain yang kesurupan dengan cara dibacakan mantra-mantra. Kesurupan adalah kondisi dimana makhluk halus masuk kedalam jasad tubuh seseorang sehingga orang

\footnotetext{
${ }^{38}$ Geertz, Religion of Java, 14.

${ }^{39}$ Al-Asyqar, 'Alam al-Jinn wa al-Syayathin, 31.

${ }^{40}$ Heddy Shri Ahimsa-Putra, "The Living al-Qur'an: Beberapa Perspektif Antropologi," Walisongo: Jurnal Penelitian Sosial Keagamaan 20, no. 1 (30 Mei 2012): 236-37, https://doi. org/10.21580/ws.20.1.198.

${ }^{41}$ Peneliti, "Wawancara dengan Agung, Ketua Paguyuban Seni Jaranan Kridho Nogo Loreng, Dusun Pamongan, Desa Caluk, Kecamatan Slahung, Ponorogo"; Peneliti, "Wawancara dengan Longgar, Ketua Paguyuban Seni Jaranan Turonggo Seto, Dusun Manyur, Desa Crabak, Kecamatan Slahung, Ponorogo."
} 
tersebut menjadi hilang kesadaran, mampu melakukan hal-hal yang diluar logika, dan jiwanya dipengaruhi oleh makhluk halus tersebut.

Sebelum pertunjukan, diadakan ritual membuka pintu gaib. Setiap pawang harus mengetahui danyang atau penunggu desa. Pawang juga melakukan ritual pada malam hari untuk meminta ijin untuk keselamatan para penari jaranan. Pada saat dilokasi sebelum diadakan pertunjukan pawang memasang pagar gaib dan menyiapkan uborampe. Uborampe digunakan untuk menghadirkan makhluk halus dengan menggunakan mantra. Setelah selesai pertunjukan pawang mengembalikan makhluk halus ke alam gaib dengan membacakan mantra penutup pintu gaib. ${ }^{42}$

Adapun praktek pembacaan doa-doa maupun ayat-ayat al-Qur'an yang biasanya diterapkan dalam kesenian Jaranan Thek terdiri dari surat al-Fatihah, al-Ikhlas, al-Falaq, al-Nas, dan Yasin. ${ }^{43}$ Tidak hanya itu, terkadang dipergunakan lafadh-lafadh khusus yang identik dengan agama Islam, seperti Allahu Akbar dan bacaan syahadat. Dengan adanya fenomena tersebut, maka semakin memperkuat pernyataan sebelumnya bahwa kesenian Jaranan Thek di Ponorogo merupakan bukti keberadaan sinkretisme antara tradisi pra-Islam dengan ajaran agama Islam.

\section{PENUTUP}

Sebagaimana kesenian Reyog Ponorogo, sejarah awal kesenian Jaranan Thek di Ponorogo terkait dengan Kerajaan Kediri dan Kerajaan Bantarangin (Ponorogo). Kesenian Jaranan Thek bersumber dari kesenian jaranan di Kediri yang kemudian dikembangkan para seniman di Ponorogo. Selain itu, diyakini bahwa kesenian Jaranan Thek sudah ada sejak zaman Kerajaan Wengker. Kesenian ini dinamakan Jaranan Thek karena diambil dari barongan atau caplokan kepala naga yang disebut Thek dan berbunyi "thek" ketika dibuka dan ditutup. Pada tahun 2009 berdirilah paguyuban Jaranan Thek pertama bernama Turonggo Wengker di Kecamatan Jetis (Kabupaten Ponorogo) dan selanjutnya pada 2017 dibentuk Ikatan Seni Jaranan Thek Ponorogo (ISJTP) sebagai organisasi pemersatu antar paguyuban Jaranan Thek di Ponorogo. Selain untuk pelestarian kebudayaan masyarakat Ponorogo, kesenian Jaranan Thek berfungsi sebagai sarana hiburan bagi masyarakat Ponorogo.

Demi pelestarian kesenian Jaranan Thek, maka komunitas kesenian ini melakukan inovasi dalam pementasan Jaranan Thek. Di antara inovasi tersebut adalah [1] penyisipan kisah Kelono Sewandono (dari Kerajaan

${ }^{42}$ Hesti Wijayanti, "Pawang dalam Seni Pertunjukan Jaranan di Desa Sranten Boyolali" (Universitas Negeri Semarang, 2016), 14.

${ }^{43}$ Peneliti, "Wawancara dengan Agung, Ketua Paguyuban Seni Jaranan Kridho Nogo Loreng, Dusun Pamongan, Desa Caluk, Kecamatan Slahung, Ponorogo.” 
Bantarangin) dengan Dewi Songgolangit (dari Kerajaan Kediri), [2] variasi lagu (dengan shalawatan, tembang Jawa, Campursari, maupun lagu populer di masyarakat), [3] penambahan alat musik modern (misalnya, drum dan organ elektrik) sambil tetap mempertahankan gamelan, [4] kombinasi dengan kesenian lain (misalnya, tari tayuban dan jathilan), dan [5] penyelarasan dengan ajaran agama Islam (misalnya, doa, ayat, maupun lafadh bernuansa Islam).

Kesenian Jaranan Thek berkembang di kalangan masyarakat Islam Abangan yang masih mempertahankan tradisi-tradisi animisme, dinamisme, Hindu, dan Buddha yang ada sebelum kedatangan agama Islam, misalnya pemakaian sesajen, persembahan kepada makhluk halus, dan permintaan bantuan kepada makhluk halus agar merasuki pemain Jaranan Thek. Dialektika Jaranan Thek dengan agama Islam sangat menonjol dalam bentuk sinkretisme setelah unsur-unsur keislaman dimasukkan dalam kesenian Jaranan Thek, misalnya ketika pawang (gambuh) menggunakan ayat-ayat, doa-doa, atau lafadh-lafadh bernuansa keislaman untuk memulai ataupun mengakhiri pementasan, serta menyadarkan pemain yang kesurupan.

Pementasan kesenian Jaranan Thek selalu diwarnai dengan kesurupan para pemain (atau bahkan penonton) ketika pementasan Jaranan Thek. Oleh karena itu, sebaiknya para seniman memberikan penjelasan seperlunya kepada para penonton Jaranan Thek mengenai hal ikhwal kesurupan sebelum diselenggarakan pementasan, termasuk tentang keimanan terhadap makhluk gaib. Selain itu, kajian lanjutan mengenai respon pemerintah maupun kalangan para tokoh agama Islam terhadap kesenian Jaranan Thek dapat dilakukan untuk lebih mendalami permasalahan ini. 


\section{DAFTAR RUJUKAN}

Ahimsa-Putra, Heddy Shri. "The Living al-Qur'an: Beberapa Perspektif Antropologi." Walisongo: Jurnal Penelitian Sosial Keagamaan 20, no. 1 (30 Mei 2012): 235-60. https://doi.org/10.21580/ws.20.1.198.

Aizid, Rizem. Islam Abangan dan Kehidupannya: Seluk Beluk Kehidupan Islam Abangan. Yogyakarta: Dipta, 2015.

Al-Asyqar, Umar Sulayman. 'Alam al-Jinn wa al-Syayathin. Kuwait: Maktabah al-Falah, 1984.

Aminulah. "Sinkretisme Agama dan Budaya dalam Tradisi Sesajen di Desa Prenduan." Dirosat 2, no. 1 (2017).

Budianingsih, Sri Heni Pawarti. "Fungsi Seni Kuda Lumping bagi Masyarakat Jawa di Desa Seminai Kecamatan Kerinci Kanan Kabupaten Siak.” Jom Fisip 2, no. 1 (2015).

Effendy, Bahtiar. Islam dan Negara: Transformasi Gagasan dan Praktik Politik Islam di Indonesia. Jakarta: Democracy Project, 2011.

Gazalba, Sidi. Pandangan Islam tentang Kesenian. Jakarta: Bulan Bintang, 1977.

Geertz, Clifford. Religion of Java. Chicago: The University of Chicago Press, 1990.

Holt, Claire. Melacak Jejak Perkembangan Seni di Indonesia. Bandung: Arti Line, 2000.

Israr, C. Sejarah Kesenian Islam. Jakarta: PT Pembangunan, 1950.

Khotijah, Hariyana. "Eksistensi Budaya Sesajen dalam Pernikahan Adat Jawa Di Desa Leran Kecamatan Senori Kabupaten Tuban." UIN Sunan Ampel, Surabaya, 2018.

Mitanto, Maulana dan Abraham Nurcahyo. "Ritual Larung Sesaji Telaga Ngebel Ponorogo: Studi Historis dan Budaya.” Agastya: Jurnal Sejarah dan Pembelajarannya 2, no. 2 (2012).

Muchtarom, Zaini. Islam di Jawa dalam Perspektif Santri dan Abangan. Jakarta: Salemba Diniyah, 2002.

Nugraheni, Whinda Kartika. "Bentuk Penyajian Kesenian Tari Jaranan Thik di Desa Coper, Kecamatan Jetis, Kabupaten Ponorogo, Jawa Timur." Universitas Negeri Yogyakarta, 2015. 
358 Ahmad Choirul Rofiq, Erwin Yudi Prahara

Purwowijoyo. Babad Ponorogo. Ponorogo: Dinas Pariwisata dan Seni Budaya Pemerintah Kabupaten Ponorogo, 1985.

Rofiq, Ahmad Choirul. "Kebijakan Pemerintah terkait Hak Sipil Penghayat Kepercayaan dan Implikasinya terhadap Perkembangan Penghayat Kepercayaan di Ponorogo." Kodifikasia 8, no. 1 (2014).

Romadhon, Dicky Reza. "Menelisik Nilai-Nilai Kearifan Lokal dalam Upacara Tradisi Larung Sesaji di Telaga Sarangan, Desa Sarangan, Kecamatan Plaosan, Kabupaten Magetan.” Universitas Negeri Malang, 2013.

Sodiqin, Ali. "Dasar Teologis Integrasi Islam dan Budaya Lokal." Dalam Islam dan Budaya Lokal. Yogyakarta: UIN Sunan Kalijaga, 2009.

Wijayanti, Hesti. "Pawang dalam Seni Pertunjukan Jaranan di Desa Sranten Boyolali.” Universitas Negeri Semarang, 2016.

W.W. Sharrock, D.W. Francis, E.C, Cuff. Perspectives in Sociology. London: Routledge, 1998. 